comes under this heading, but elsewhere the emphasis is different. In Portugal $£ 635,225$ went on science and medicine, $£ 584,270$ on education, and only $£ 163,597$ on the arts. Armenian communities throughout the world $(£ 552,975)$, social and cultural projects in South America $(£ 820,738)$ and gifts to charities in the Middle East and elsewhere made up the rest of the budget.

In Britain the foundation supports some fascinating projects. The University of Bristol was given a grant to study the social and psychological consequences of development and rehousing in Bristol, and group homes for former psychiatric patients and for unsupported mothers and their children have been supported in Colchester and Nottingham. The University of Kent at Canterbury was given $£ 35,500$ towards the cost of a theatre and arts centre at the university, and the universities of Warwick and Wales (Bangor) similar sums for similar projects. At Cambridge grants have been given to continue work on the publication of a new complete edition of the Linear B tablets from Knossos, and to study the demography and social structures of 18th century Britain. The University of York has perhaps the most unusual project of all: $£ 7,850$ to study the internal government of British universities.

\section{More for Research Associations?}

At least one of the co-operative industrial research associations will be supported more generously by the Ministry of Technology in the year ahead. It is understood that the ministry has offered the Welding Research Association substantially improved terms of grants, and that the ministry is willing to contribute to the marginal income of the association no less than 150 per cent of what can be raised by means of subscriptions from industrial companies. The standard form of grant entails that the government should match the industrial contribution pound for pound. No doubt the ministry will be quick to inform other research associations that the welding research association is in a special position dictated by the character of its work as a provider of help and advice to a great many industries whose needs cannot always be specified in advance. But there is bound to be a feeling among the research associations that what is good for welding would also be good for others. The way in which the government is encouraging mergers between industrial companies is in any case a good reason for looking again at the financing of the research associations.

\section{In Charge of Static}

A New group has been set up by the Institute of Physics and the Physical Society to study static electrification. The new group will encourage study in the generation, dissipation and convection of electric charge on, in and between solids, liquids and gases, and will include both desirable and undesirable electric charges. It is suggested that the group might consider theories of contact electrification, electrostatic charge generation and dissipation, the electrification of liquids during pipeline flow, electrostatic precipitation and coating, and the hazard from static electricity in the textile, chemical, petroleum and photographic industries.

The first chairman of the provisional committee will be Dr. P. S. H. Henry of the Shirley Institute, and the secretary will be Dr. N. Gibson of Imperial Chemical Industries Dyestuffs Division. There has so far been very little fundamental work on static electrification, and although Dr. Henry believes that the industrial side is the most important (static interferes with production, and can cause fires) he is also hoping to stimulate some fundamental work. Already one three-day conference has been arranged, to be held in London from May 8 to 10 , and next year it is likely that regular half-day meetings will be arranged. Although the terms of reference of the group include a variety of disciplines, the problems will apparently be common to all.

\section{Uproar at Millom}

SPRAY steelmaking, a new process developed by the British Iron and Steel Research Association (Nature, 212,331 ; 1966) seems so far to have created more problems than it has solved. The process, which offers the nearest approach yet to continuous steelmaking at a capital cost said to be less than a third of that of conventional equipment, was developed at the Cumberland works of Millom Hematite Ore and Iron Company. The company, which has run the process so far only on a relatively small scale, is anxious to go ahead with an ambitious plan which would give it a steel capacity of 500,000 tons per year, and continuous casting equipment to make best use of the new process. The plans, which necessarily include gas cleaning equipment, would cost $£ 1$ million, and the Iron and Steel Board, which has to approve all expenditure in the industry of more than $£ 100,000$, deferred its decision. This was taken as a refusal, for the board had said that it was reluctant to approve the creation of small scale capacity when the trend is towards large scale operation. This week the board gave grudging approval for Millom's plans, adding that it would have prohibited the move if it had had the power to do so.

The deferment of Millom's application had caused uproar in the north-west, aggravated by the success of Lancashire Steel Manufacturing Co., Ltd., in going ahead with a spray steelmaking plant capable of making 50 tons of steel per hour. This is producing steel only three months after building startedremarkable in an industry where new processes characteristically take a long time to catch on. Millom's case was given emotional impact because the town relies almost entirely on the ironworks for employment and without it would be hard pressed to survive. Ironically, since Millom is in a development area, now that it has permission to go ahead the government will make a substantial contribution to the cost of the plant, possibly as much as $£ 450,000$.

Despite the bitter arguments, the future for spray steel looks promising. Apart from Lancashire Steel, there are hints that another British company-possibly United Steel-is interested. A Canadian company, Dominion Foundries and Steel, Ltd., has already taken out a licence from BISRA to develop its own spray unit. The company intends to do theoretical research on the process before building a pilot plant. Criticisms in the United States and Canada include the possibility that the reaction chemistry could play havoc with furnace refractory linings (BISRA says that as the reactions do not take place in 